\title{
CS Research Soure \\ Application and Validation of a Biotic Ligand Model for Calculating Acute Toxicity of Lead to Moina Dubia in Lakes of Hanoi, Vietnam
}

Hong Thi Pham

Hanoi University of Science and Technology

Long Duc Vu

Hanoi University of Science and Tecnology

Ngoc Chi Le

Hanoi University of Science and Technology

Thu-Huong Thi Hoang ( $\nabla$ huong.hoangthithu@hust.edu.vn )

Hanoi University of Science and Technology https://orcid.org/0000-0003-1132-2884

\section{Research Article}

Keywords: Lead toxicity, acute toxicity, Moina dubia, zooplankton, tropical lakes, urban lakes

Posted Date: May 26th, 2021

DOI: https://doi.org/10.21203/rs.3.rs-485436/v1

License: (a) (i) This work is licensed under a Creative Commons Attribution 4.0 International License.

Read Full License 


\section{Abstract}

It is increasingly being recognized that biotic ligand models (BLMs) are valuable in the risk assessment of metals in aquatic systems. The authors investigated the effect of $\mathrm{pH}, \mathrm{Ca}, \mathrm{Mg}, \mathrm{K}, \mathrm{Na}$ on the acute toxicity of $\mathrm{Pb}$ to Moina dubia, native zooplankton in lakes of Hanoi, Vietnam. Calcium, Magnesium and $\mathrm{pH}$ strongly influenced acute $\mathrm{Pb}$ toxicity to Moina dubia. Based on this data set, a acute Pb-BLM for Moina dubia was developed according to condition of Hanoi lakes. The developed BLM was shown, in an independent validation with data on acute toxicity test on natural water sets, to be capable of predicting chronic $\mathrm{Pb}$ toxicity with $81.3 \%$ accuracy. The results proved that BLM can be useful tool for calculating the acute toxicity based on water-quality criteria in lake of Hanoi.

\section{Introduction}

Lead is one of the non-essential most toxic metals to the organism (Pareja-Carrera et al. 2020). The lead is used widely in battery manufacturing, aluminum industry, coating technology, printing and mining, and metallurgy. Lead emission in traffic and burning fossil fuels in industrial zones also cause lead pollution after it deposits to water or soil environment (Borase et al. 2021). In many areas, lead pollution happened on the water surface. The concentration of lead in the water surface of Bangladeshi rivers ranges 17$10180 \mu \mathrm{g} / \mathrm{L}$ (Uddin and Jeong 2021). In the Honghu, Guchenghu, and Taihu rivers in China, lead deposited as high as 37.5-48.75 mg/kg (Yao et al. 2009). In Vietnam, lead concentrations in surface water of Hanoi such as in To Lich River and Kim Nguu Rivers were in the range of 100-220 $\mu \mathrm{g} / \mathrm{L}$ due to untreated wastewater (Nguyen, 2007). Another study studied lead concentrations in the northern rivers near the mining areas, Thai Nguyen the lead concentration in water used for agricultural irrigation was from 93.4 to $111.5 \mu \mathrm{g} / \mathrm{L}$ (Nguyen, 2007). Lead is considered a dangerous element and may directly affect the growth and reproduction of organisms. The International Agency for Research on Cancer (IARC) has listed lead and its compounds as potentially carcinogenic substances in humans. The question is how to assess the risk of metal to aquatic ecosystems. The biotic ligand model (BLM) was built to predict the ecotoxicology and do a risk assessment. The BLM has been developed for more than twenty years and had been officially applied in many countries (British Collumbia 2019, Tobiason et al. 2018). In Asia, the BLM was developed for aquatic species in China in 2012 (Wang et al. 2011) and recently in 2017 (Wang et al. 2017, Zhou et al 2011). In Japan, studies on BLM have been carried out since 2013 but mainly based on toxicological data in other countries (Hayashi 2013, Naito et al, 2010). Most studies on the BLM in tropical regions used the toxicological data collected from the temperate zone (Shoji anh Taniguchi 2016).

The BLMs had been developed for Cu (De Schamphelaere and Janssen 2002), Ni (Deleebeeck et al, 2008, 2009) and Cd (Clifford and McGeerand 2010). Lead is one of the metals studied by USEPA in the BLM development center (DeForest et al. 2017). The BLM has been evolving for a long time but mostly on endemic species in Europe and America such as Baetis tricaudatus (mayfly), Ceriodaphnia dubia (cladoceran) (Nys et al. 2014), Daphnia magna (DeForest et al 2017), and Pimephales promelas (Mageret al. 2011). Due to the differences in the body size, metabolism rate, and adsorption ability of surface ligan, 
the application of those model constants of Europe and American species for those living in the tropical region. The characteristic of surface water in the Tropical area would affect the ability to predict the acute toxicology of metal. However, there are still limited studies on BLM in eutrophic lakes.

Moina dubia is a widely distributed zooplankton in the aquatic bodies in Viet Nam (Le et al., 1999), Thailand, Philippines, Indonesia (Korovchinsky 2013), and Sri Lanka (Fernando, 1979). The eutrophic lake plays controlling fertility and toxic algae in the lake. Moina dubia is important zooplankton in the food chain to maintain the diversity of species in the food chain of lakes (Adeyemov 1994). Moina in general and M. dubia are very sensitive to pesticides and metals (von der Ohe P.C., Liess M. 2004). Many studies have selected Moina to study metal toxicity (Gama-Flores 2008, Borase et al, 2021, Zou and Bu 1994, Sheedy et al. 1991) ). This paper discusses a BLM model development for urban eutrophic lakes on Moina dubia, native zooplankton in Vietnam (Borase et al, 2021).

\section{Materials And Methods}

\subsection{Study species and EC50 determination}

Moina dubia were collected from Truc Bach Lake ( $\left.+21^{\circ} 02^{\prime} 40.8^{\prime \prime} \mathrm{N} ;+105^{\circ} 5^{\prime} 22,1^{\prime} \mathrm{E}\right)$ located in Hanoi. They are abundant in this small urban and highly eutrophic lake (Hoang et al 2017, Pham et al. 2018). In the laboratory, M. dubia were isolated using a Pasteur pipette. They were cultured in a common basal medium (Conklin and Provasoli 1977) at a temperature of $\sim 24^{\circ} \mathrm{C}, \mathrm{pH}=\sim 7.5$, and under the ambient light and a photoperiod of $12 \mathrm{~h}$ light: $12 \mathrm{~h}$ dark cycle. The acclimation period lasted one month (ca. $5 \mathrm{e} 7$ generations) to minimize the lake environmental background on the toxicity test results (Sorin and Choi, 2012). M. dubia were fed ad libitum with Chlorella vulgaris. C. vulgaris was centrifuged and washed to remove culture nutrients before feeding $\mathrm{M}$. dubia at a density of 1106 cells $/ \mathrm{mL}$. The newborn $\mathrm{M}$. dubia ( $<24 \mathrm{~h}$ old $)$ were elected randomly from the culture for toxicity tests.

\subsection{Water characteristic of eutrophic urban lake}

Water samples were collected from 12 lakes surround Hanoi, including two natural suburban lakes and ten closed urban lakes. Collective sampling in five places in the lake was applied. Samples were transferred to the laboratory and stored at 4oC. The physical and chemical parameters $(\mathrm{pH}, \mathrm{DOC}$, chlorophyll-a, $\left.\mathrm{Ca}^{2+}, \mathrm{Mg}^{2+}, \mathrm{Na}^{+}, \mathrm{K}^{+}\right)$. Monitoring for water quality was conducted from January 2018 to May 2019.

\subsection{Experimental Design}

To investigate the effects independently of main cations including $\mathrm{Ca}^{2+}, \mathrm{Mg}^{2+}, \mathrm{Na}^{+}, \mathrm{K}^{+}$and $\mathrm{H}^{+}$on lead toxicity, we change one cation concentration while keeping all other cation concentrations as low as possible. The $\mathrm{Ca}^{2+}$ concentration changed from $4-56 \mathrm{mg} / \mathrm{l}$, the $\mathrm{Mg}^{2+}$ concentration changed from $2.99-$ $71.2 \mathrm{mg} / \mathrm{l}, \mathrm{Na}^{+}$concentration changed from $3.5-60.7 \mathrm{mg} / \mathrm{l}, \mathrm{K}^{+}$changed from $1.85-2.29 \mathrm{mg} / \mathrm{l}$, while pH was kept at 7.5. The $\mathrm{pH}$ changed from 7 to 8.5 since M.dubia adapt in the basic condition, so $\mathrm{pH}<7$ 
would cause uncomfortable for the metabolism of M.dubia. The composition of the experimental sets was described in Table 1. The range of the main cation was classified based on the characteristics of natural water in Hanoi lake. Each cation set was .ed pH and put into the room temperature until it met the stability condition before using for acute tests. Each set was repeated four times and comprised of at least five different cation concentrations. The selected cation concentrations represented a range of water surface characteristics of the urban Lake of Hanoi, Viet Nam.

\section{Preparation of the Test Solutions}

$\mathrm{CaCl}_{2}, \mathrm{MgSO}_{4}, \mathrm{NaCl}, \mathrm{KCl}$ and $\mathrm{HCl}, \mathrm{NaOH}$ (purity $>98 \%$, Merck, Germany) were used to make stock solutions. For each essay, $\mathrm{Pb}$ (NO3)2 was added into the control mediums to make up the concentration series of lead. Except for the $\mathrm{pH}$ set, the medium was .ed at $\mathrm{pH} 7.5$ in the range of eutrophic lakes. The buffer MOSP was used for the stability of the solution. All the medium was put into a $250 \mathrm{C}$ room one day before being used for acute test to reach the near-equilibrium condition.

\section{Acute Toxicity Tests.}

The 24-h immobilization assay was conducted with neonate Moina dubia ( $<24 \mathrm{~h}$-old age) following the guideline 202 of OECD (24). The organisms were acclimated in the laboratory 5-6 generations before being used for toxicology tests. For each test, six treatments (control and five different lead concentrations) were performed from the lowest to the highest lead concentration with four replications. The medium was filled $50 \mathrm{ml}$ in each cup. After $24 \mathrm{~h}$ exposure in the $25^{\circ} \mathrm{C}$ and $12 \mathrm{~h}$ light: $12 \mathrm{~h}$ dark, the number of immobilized neonates in each cup was checked and counted.

\section{Estimate the equilibrium condition of ion and biotic ligand}

Prepare $\mathrm{Pb}^{2+}$ adsorbent solution with five different concentrations of $50 \mu \mathrm{g} / \mathrm{L}, 100 \mu \mathrm{g} / \mathrm{L}, 200 \mu \mathrm{g} / \mathrm{l}$ and $300 \mu \mathrm{g} / \mathrm{I}$ prepared with standard solution $\mathrm{Pb}(\mathrm{NO} 3) 2 \mathrm{~g} / \mathrm{I}$ (Merk, Germany) in a soft water environment (hardness in Ca was $50 \mu \mathrm{g} / \mathrm{L}$, with minimum nutritional ingredients). The $\mathrm{pH}$ was .ed by $\mathrm{NaOH}$ or $\mathrm{HCl}$, to three levels of $6.5,6.8$, and 7 . The reconstituted solution is allowed to stabilize for 30 minutes before placing $10 \mathrm{M}$. dubia ( $<24 \mathrm{~h}$ old) neonates in beakers with different lead concentrations and the lead-free solution as the control medium. The volume of the adsorbent solution was $250 \mathrm{ml}$. Samples of $10 \mathrm{ml}$ were collected every 15 minutes at the initial adsorption stage until 1-hour and then every 30 minutes. Samples taken were then measured $\mathrm{Pb} 2+$ concentration to find the adsorption equilibrium coefficient.

Metal adsorption on the contact surface of living organisms is a form of complex bonds between metals and functional groups on the surface of biological cells. The adsorption equilibrium coefficient was calculated by the Langmuir adsorption equilibrium equation (Farvus et al. 1989).

\subsection{Model validation}

The acute toxicity tests of lead to M.dubia were conducted with the natural water collected from 12 lakes as the control medium. The acute tests were performed by six lead treatments (one control and five 
different lead concentrations) and replicated four times (See 2.2). Values of EC50-24h received the test were then used for validating the developed BLM by .calibrating the lead accumulation coefficient.

\subsection{Mathematical Description of the BLM.}

The equation of calculation BLM was described below:

Where $\mathrm{EC}_{50\left(\mathrm{~Pb}^{2+}\right)}$ is the free lead ion activites resulting in $50 \%$ of $24 \mathrm{~h}-M$.dubia immobilized after $24 \mathrm{~h}$ of exposure.

$$
E C_{50}=\frac{f_{P S B L}^{\circ}}{\left(1-f_{P B B L}^{0}\right) \cdot \mathrm{K}_{P B B L}} \cdot\left\{1+K_{C a B L}\left(C a^{2+}\right)+K_{M g B L}\left(M g^{2+}\right)+K_{\text {NaBL }}\left(N a^{+}\right)+K_{K B L}\left(K^{+}\right)+K_{H B L}\left(H^{+}\right)\right\}
$$

$\left(\mathrm{Ca}^{2+}\right),\left(\mathrm{Mg}^{2+}\right),\left(\mathrm{Na}^{+}\right),\left(\mathrm{K}^{+}\right)$and $\left(\mathrm{H}^{+}\right)$are concentration of described ions in the water bodies. The stability constants $\mathrm{K}_{\mathrm{HBL}}, \mathrm{K}_{\mathrm{MgBL}}, \mathrm{K}_{\mathrm{CaBL}}, \mathrm{K}_{\mathrm{NaBL}}, \mathrm{K}_{\mathrm{KBL}}$ were calculated from the relation between $\mathrm{pH}, \mathrm{Mg}^{2+}, \mathrm{Ca}^{2+}, \mathrm{Na}^{+}$, $\mathrm{K}^{+}$and $\mathrm{EC} \mathrm{Pb}_{\mathrm{Pb}_{2} \cdot}$. Assumption of the BLM concept is the linear relationships observed between $\mathrm{EC} 50_{(\mathrm{Pb} 2+)}$ and the mentioned ion.

\section{Data treatment and Statistics}

Speciation calculations were conducted using Windermere humic aqueous model (WHAM) Ver 7.02 (http://www.ceh.ac.uk/products/software/ wham/). Speciation calculations were performed for all experimental treatments. $\mathrm{EC}_{50}-24 \mathrm{~h}$ expressed as dissolved lead were calculated from observed immobilities at each lead concentration. Twenty -four- hours expressed as free lead ion activity were calculated from observed immobilities at each calculated free lead ion activity. $\mathrm{EC}_{50}$ were calculated using the trimmed Spearman Karber method (Hamilton, 1977). All linear regressions (see further) were calculated using SPSS 20 . The stability constants were received by solving the system of equation coding in Matlab environment.

\section{Results And Discussion}

\subsection{Geochemistry of water in the trophic lakes}

The water temperature in eutrophic lakes varied widely from 16 to $35.4^{\circ} \mathrm{C}$. The temperature dropped from $15.5-16.5^{\circ} \mathrm{C}$ in the winter but increased to $35.4^{\circ} \mathrm{C}$ on the summer day.

The median $\mathrm{pH}$ value of eutrophic lakes in Hanoi in the database was deviated from neutral to slightly basic (7.3 - 8.5). Aquatic organizations would get troubles when living in permanently alkaline environments (Sakamoto et al. 2018). Many factors would affect the change in the $\mathrm{pH}$ of water bodies. The bloom of algae, which uptake bicarbonate during the photosynthesis process, can break the $\mathrm{H}+$ balance in the water, causing the pH variation day and night (Acuña-Alonso 2020). Second, anthropogenic activities, including discharging untreated domestic wastewater, would also affect the $\mathrm{pH}$ 
of urban lakes. The data on nutrients $(\mathrm{N}$ total $=30,4 \pm 6,6 \mathrm{mg} / \mathrm{L} ; \mathrm{P}$ total $=0.97 \pm 0,2 \mathrm{mg} / \mathrm{L}$; and chlorophyll-a $(201,1 \pm 0,44 \mathrm{mg} / \mathrm{m} 3)$ in the eutrophic lakes which was in agreement with a previous study (von der Ohe and Liess 2004) (Table 1). The blooming of algae would significantly change the $\mathrm{pH}$ value and the daily dissolved oxygen (DO) in the surface water. The DO varied widely from 4.06 to $11.24 \mathrm{mg} / \mathrm{L}$ depending on the metabolism of the algae (Cook and Gale 2005). The calcium and magnesium concentration was approximately varied $20.5 \mathrm{mg} / \mathrm{L}-56.3$, and $4.8 \mathrm{mg} / \mathrm{L}-33 \mathrm{mg} / \mathrm{L}$ respectively.

\subsection{Effect of major cation on acute Pb toxicity}

An increase in the concentration of $\mathrm{Ca}^{2+}, \mathrm{Mg}^{2+}, \mathrm{Na}^{+}$, and $\mathrm{K}^{+}$resulted in an elevated $24-\mathrm{h} \mathrm{EC}_{50} \mathrm{~Pb}^{2+}$. In these bioassay sets, observed EC50s ranged from 283 to $518 \mathrm{nM}$ for free lead ion activity. The result show a positive linear relations $(p<0.05)$ between activities of $\mathrm{Ca}^{2+}, \mathrm{Mg}^{2+}, \mathrm{Na}^{+}$, and $\mathrm{K}^{+}$(Figure $\left.1 \mathrm{a}-\mathrm{d}\right)$.

A positive linear regression between calcium concentration and value of EC50s indicated that calcium could reduce the toxic effect of lead on M.dubia. The impact of calcium on metal toxicity has been observed on many different aquatic species (Markich and Jeffree, 1994, Chun Sang 2016). According to Riethmuller, N., (2000), hardness does not directly affect the types speciation of lead in the medium but is influenced by strong changes in the acid-base balance of the solution, thereby indirectly changing the existence of the lead in the solution (Riethmuller et al. 2000). The mobility lead concentration decreased when increasing the concentration of calcium in the medium. The second reason, when $\mathrm{Ca}^{2+}$ and $\mathrm{Pb}^{2+}$ are highly concentrated in the ligand surface, M.dubia will prioritize absorption of calcium over the lead during metabolism and cell charge balance. High calcium concentration on the cell membranes of organisms can decrease the transport rate of lead across the cell membrane. thereby reducing the penetration of lead into the body (Favus et al. 1989, Markich and Jeffree 1994).

The $\mathrm{Mg}^{2+}$ was strongly bound to function groups (- $\left.\mathrm{COOH}, \mathrm{CHO}-..\right)$ on the surface of ligand and compete with II valence metals on ligand surfaces (Shen et al. 2016). The $\mathrm{Mg}^{2+}$ concentration on the surface of the ligand created a positive charge potential on the surface of the organism which can limit lead absorption into the body. Experimental results show that when the magnesium concentration in the environment increases, the amount of lead entering the organism decreases, thereby reduced the toxicity of lead to M.dubia.

$\mathrm{Na}^{+}$and $\mathrm{K}^{+}$were two metal competed strongly with $\mathrm{Pb}^{2+}$ on the surface of the organism (Zhao et al. 2017, Renaudin et al. 2018). The density of $\mathrm{Na}^{+}$and $\mathrm{K}^{+}$would create a positive electric potential on the biological absorption surface, which reduces the possibility of $\mathrm{Pb}^{2+}$ transported inside the organism. During the transportation of a $\mathrm{Pb}^{2+}$ ion through the cell membrane, two $\mathrm{Na}^{+}$or $\mathrm{K}^{+}$ions would be pumped out to maintain the charge balance on the membrane. Thus, $\mathrm{Na}^{+}$and $\mathrm{K}^{+}$also play a crucial role in regulating the absorption of lead into the body. An increase of $\mathrm{Na}^{+}$or $\mathrm{K}^{+}$concentration makes it difficult to absorb $\mathrm{Pb}^{2+}$, thus reduces the toxicity of lead. 
The $\mathrm{pH}$ test was conducted in the range of 7-8.5 to give observed $\mathrm{EC}_{50}-24 \mathrm{~h}$ range from 241 to $518 \mathrm{nM}$ for dissolved lead. The linear relationship between $\left(\mathrm{H}^{+}\right)$and 24-h $\mathrm{EC}_{50}\left(\mathrm{~Pb}^{2+}\right)$ would indicate the possibility of proton competition at the ligand surface (Figure 1e). Two possible mechanisms can be proposed. First, $\mathrm{pH}$ can affect the speciation of lead in the medium. When $\mathrm{pH}>7.5$, lead exists in the flexible forms $\mathrm{Pb}^{2+}$ and $\mathrm{Pb}(\mathrm{OH})_{2}$ or $\mathrm{PbCO} 3$ of these forms together have a toxic effect on M.dubia (Farrell 2012). When the $\mathrm{pH}$ is low, there was mainly $\mathrm{Pb}^{2+}$ which highly interacted with functional groups on the ligand surface. Second, the $\mathrm{pH}$ in the medium would affect the micro-environment of the biotic ligand such as for fish (Playle 1992) or for invertebrates (Gensemer and Playle 1999) which can affect the interaction between the specification of lead at the organism-water interface (Playle 1992). There may be a limitation in using $\mathrm{pH}$ to predict $\mathrm{EC}_{50}\left(\mathrm{~Pb}^{2+}\right)$ in the $\mathrm{pH}$ range from 7 to $8.6\left(\mathrm{R}^{2}=0.65\right)$. For $\mathrm{pH}$ in the range from 7 to 8.3 , the BLM concept succeeds to calculate EC50s from $\mathrm{pH}$. The reason for that could be, at $\mathrm{pH}=>8.3$ the lead in the medium mostly in $\mathrm{PbCO} 3$ and $\mathrm{Pb}(\mathrm{OH}) 2$ form. In that case, not only $\mathrm{Pb} 2+$ but other speciation of lead were bound to the ligand and transport to act toxin. Other studies reported that the forms as $\mathrm{Pb}(\mathrm{OH})_{2}$ or $\mathrm{PbCO}_{3}$ had low toxicity than the flexible form (Antunes and Kreager 2014). For this reason, we used the formula that expressed the relationship between $\mathrm{pH}$ in the range from 7 to 8.3 and EC50 to calculate the constants $\mathrm{K}_{\mathrm{HBL}}, \mathrm{K}_{\mathrm{MgBL}}, \mathrm{K}_{\mathrm{CaBL}}, \mathrm{K}_{\mathrm{NaBL}}, \mathrm{K}_{\mathrm{KBL}}$.

\subsection{Estimation of BLM Parameters.}

The intercept and slope were obtained by conducting a Linear regression analysis of the relationship between $\mathrm{EC}_{50}\left(\mathrm{~Pb}^{2+}\right)$ and cation activity $\left.\mathrm{Ca}^{2+}, \mathrm{Mg}^{2+}, \mathrm{Na}^{+}, \mathrm{K}^{+}, \mathrm{H}^{+}\right)$. Combination the effect of the main cation, the matrix was expressed in equation (2)

$$
\begin{aligned}
& -1 K_{\text {CaSI }}+0,025 K_{1 \& B L}+0,013 K_{\text {NaBL }}+0,06 K_{K B L}+0,085 K_{H E L}=-0,23 \\
& 0,037 K_{\text {CaBS }}-K_{\text {MGESL }}+0,267 K_{\text {NaBL }}+0,012 K_{\text {KBL }}+0,175 \mathrm{~K}_{\text {HBL }}=-0,45 \\
& 0,014 K_{\text {CaBI }}+0,017 K_{\mathrm{MEBL}}-1 K_{\mathrm{NaBL}}+0,008 K_{\mathrm{KBI}}+0,049 K_{\mathrm{HBL}}=-0,146 \\
& 0,0164 K_{\text {CaBL }}+0,022 K_{1 \& B D}+0,117 K_{\text {NaBL }}-1 K_{K B L}+0,06 K_{\text {HEL }}=-0,196 \\
& 0,056 K_{\text {CaBI }}+0,022 K_{\text {IEEIL }}+0,107 K_{\text {NaBL }}+0,011 K_{\text {KBL }}-1 K_{\text {HBL }}=-0,18
\end{aligned}
$$

The solution of this matrix after speciation calculations and linear regression analyses (Figure 1) resulted in the estimation of the stability constants $\mathrm{K}_{\mathrm{CaBL}}=0,282 ; \mathrm{K}_{\mathrm{MgBL}}=0,549 ; \mathrm{K}_{\mathrm{NaBL}}=0,173 ; \mathrm{K}_{\mathrm{KBL}}=0,247 ; \mathrm{K}_{\mathrm{HBL}}$ $=0,229$

The constants for $\mathrm{Ca}^{2+}, \mathrm{Mg}^{2+}$, and $\mathrm{Na}^{+}$were similar to those obtained for fish gills (Clifford and McGeerand 2010) and used in the BLM (Mager et al. 2011, Nys et al. 2014). The constant binding of lead to biotic ligand surface was $\left(\mathrm{K}_{\mathrm{PbBL}}=7.301\right)$ conducted in the low $\mathrm{pH}$ toxicity test based on the Langmuir equation ( $\mathrm{pH}=6.7$ ) (Zhou et al. 2011). The binding between lead and biotic ligand was similar as the $\mathrm{K}_{\mathrm{PbBL}}=7$ reported from Niyogi and Wood (2003). The biding conpetition between $\mathrm{Pb}^{2+}$ and $\left(\mathrm{H}^{+}\right)$on the 
biotic ligand was (3.72) which was less one unit than the $\log \mathrm{K}_{\mathrm{HBL}} \sim 5.4$ for fish and much lower than $\mathrm{K}_{\mathrm{HBL}}=7.6$ for Ceriodaphnia dubia when they was exposed in chornic test (Nys et al. 2014).

A large difference between $\mathrm{K}_{\mathrm{PbBL}}$ and $\mathrm{K}_{\mathrm{HBL}}$ showed $\mathrm{H}^{+}$had significant contribution in proton competition to lead on the ligand surface. In this study, the results in calculations of $\log \mathrm{K}_{\mathrm{CaBL}}=4.39, \log \mathrm{K}_{\mathrm{MgBL}}=$ 4.47, and $\log \mathrm{K}_{\mathrm{NaBL}}=3.92 \mathrm{~K}_{\mathrm{KBL}}=4.34$ (Table 2). These log K's were in the same range as the constants reported by Playle et al (1993), except for the K-constant, which has not been included in current BLMs so far (McGeer et al. 2000).

In comparison with another $\log \mathrm{K}_{\mathrm{CaBL}}$ and $\log \mathrm{K}_{\mathrm{MgBL}}$, the $\log \mathrm{K}_{\mathrm{NaBL}}$, and $\mathrm{K}_{\mathrm{KBL}}$ seem to quite high. The reason for that may because they binding to the typical biogenic chelating ligands such as aspartate, citrate, etc (Stumm and Morgan). This result suggested that $\mathrm{Na}^{+}$and $\mathrm{K}^{+}$reduce the lead toxicity not only by competition on the ligand surface but also by preventing to loss of plasma electrolytes (De Schamphelaere and Janssen 2002) .

\subsection{BLM development and validation}

To validate the BLM, the natural water samples were collected from 10 urban lakes in Ha Noi, Viet Nam. 28 synthetic tests were used to improve the model predictions. A single overall intrinsic density to $\mathrm{Pb}$ toxicity was used for all the data sets.

The predicted EC50s and observed EC50s from synthetic test waters were demonstrated in Fig 2 and Fig. 3 with $\mathrm{R}^{2}=80.5 \%$. It was recognized that the BLM-parameters estimated EC50 fit with the observed EC50s data.

$E C_{50}=\frac{f_{P b B L}^{50}}{\left(1-f_{P b E L}^{50}\right) \cdot \mathrm{K}_{P b B L}} \cdot\left\{1+K_{C a B L}\left(\mathrm{Ca}^{2+}\right)+K_{\text {SEBL }}\left(M^{2+}\right)+K_{\text {NaBL }}\left(N a^{+}\right)+K_{K B L}\left(K^{+}\right)+K_{H B L}\left(H^{+}\right)\right\}$

$\mathrm{f}^{50}$ was calibrated from 0.35 đến 0.47 and received the best performance at 0.42

Although the developed M.dubia BLM shows promise, there was still a need to further validate the data from experiments with a broader range of exposure conditions in the field with the variations of DOC concentrations. For the validation with nature water, ANOVA analysis results show that the experimental EC50 value has a significant correlation with the EC50s value calculated from the model $(P$-value $=$ 0.0001). Predictive ability of the coefficient determination model coefficient $R^{2}=75.3 \%$. (Fig. 4, 5)

In general, the $\mathrm{EC}_{50}-\mathrm{Pb}^{2+}$ values predicted by the model in the suburban lakes were greater than $\mathrm{EC}_{50^{-}}$ $\mathrm{Pb}^{2+}$ for the urban lakes. The results of the experiment also show the same trend. In urban, in addition to the highly toxic metals such as lead, there are also other metals such as arsenic and cadmium present in natural water, which increase lead toxicity. 
The results showed a significant dispersion between EC50 obtained in the lab experiments with natural water and the calculated EC50s from the model. However, the differences are acceptable. The model-

calculated $\mathrm{EC}_{50}-\mathrm{Pb}^{2+}$ values tend to be greater than $\mathrm{EC}_{50}-\mathrm{Pb}^{2+}$ values tested in inner urban lakes but was less than those tested with nature water from lakes in a suburban city (Quan Son and Tuy Lai lake). The reason is that in natural water conditions, organic matter ranges widely, from trophic lakes and eutrophic. Therefore, the coefficient of a model can be calibrated within the range of 0.38-0.9. Table 3. shows the calculated results of the model before and after the calibration, with the prediction accuracy (coefficient determination) of $81.3 \%$.

\section{Conclusion}

Biotic ligand models have proven their usefulness in predicting acute metal toxicity in natural waters based on a more complete knowledge of bioavailability-influencing water characteristics including $\mathrm{pH}$, $\mathrm{Ca}, \mathrm{Mg}, \mathrm{Na}, \mathrm{K}$. The BLM concept can be used to support development of discharge regulation into the aquatic environment. This illustrates that the incorporation of bioavailability of metals in current waterquality guidelines and risk assessments is indispensable and that further research is needed to develop $\mathrm{Pb}$ BLMs with aquatic zooplankton and also with other organisms and to investigate how these can be implemented in the risk-assessment process. Based on the present research with Moina dubia, $\mathrm{BLM}$ can provide appropriate criteria to address the risk of $\mathrm{Pb}$ in surface waters.

\section{Declarations}

\section{Ethics approval and consent to participate}

The submitted work is original and have not been published elsewhere in any form or language (partially or in full).

\section{Consent for publication}

We co authors of this article give our consent for the publication of identifiable details, which can include photograph(s) and/or videos and/or case history and/or details within the text ("Material") to be published in the Journal and Article. Therefore, anyone can read material published in the Journal.

\section{Availability of data and materials}

The datasets used and analysed during the current study are available from the corresponding author on reasonable request.

\section{Competing interests}

The authors declare that they have no known competing financial interests or personal relationships that could have appeared to influence the work reported in this paper 


\section{Funding}

The research was supported by the funding from the Ministry of Education and Training (MOET), Vietnam (Grant number: B2019-BKA.03)

\section{Authors' contributions}

- HP: Conceptualization, Methodology, Investigation, Data curation, Investigation, Visualization, Writing- Original draft preparation.

- LV: Methodology, Investigation, Coding, Visualization,

- NL: Conceptualization, Methodology, Investigation, Data curation, Investigation,

- T-HH: Supervision, Project Administration, Funding acquisition, Conceptualization, Writing- Reviewing and Editing

- All authors read and approved the final manuscript

\section{Acknowledgements:}

We thank anonymous reviewers for constructive feedback, which helped to improve the manuscript.

\section{References}

1. Acuña-Alonso, C., et al (2020) Influence of Microcystis sp. and freshwater algae on pH: Changes in their growth associated with sediment. Environmental Pollution. 263: p. 114435.

2. Adeyemov A., OladosuG. and A. Ayinla (1994) Growth and survival of fry of African catfish species, Clarias gariepinus Burchell, Heterobranchus bidorsalis Geoffery and Heteroclarias reared on Moina dubia in comparison with other first feed sources. Aquaculture. 119(1): p. 41-45.

3. B.C. Ministry of Environment and Climate Change Strategy. (2019) Copper Water Quality Guideline for Protection of Freshwater Aquatic Life-User's Guide. Water Quality Guideline Series, WQG-03-2. Prov. B.C., Victoria B.C.

4. Borase, H.P., et al. (2021) Enzymatic response of Moina macrocopa to different sized zinc oxide particles: An aquatic metal toxicology study. Environmental Research. 194: p. 110609.

5. Chun Sang, H. (2016) Study on the Effect of Heavy metals toxicity according to changing Hardness concentration using D. magna. in AGU Fall Meeting Abstracts.

6. Clifford M., McGeerand J.C. (2010) Development of a biotic ligand model to predict the acute toxicity of cadmium to Daphnia pulex. Aquatic Toxicology 98(1): p. 1-7.

7. Conklin D.E., Provasoliand L. (1977) Nutritional requirements of the water flea Moina macrocopa. The Biological Bulletin. 152(3): p. 337-350.

8. Cook D.,.Gale S. (2005) The curious case of the date of introduction of leaded fuel to Australia: implications for the history of Southern Hemisphere atmospheric lead pollution. Atmospheric 
Environment. 39(14): p. 2553-2557.

9. DeForest, D.K., et al. (2017) Development of biotic ligand model-based freshwater aquatic life criteria for lead following US Environmental Protection Agency guidelines. Environmental toxicology and chemistry, 36(11): p. 2965-2973.

10. Deleebeeck N.M., De Schamphelaere K.A. , Janssen C.R.(2009) Effects of Mg2+ and H+ on the toxicity of $\mathrm{Ni2}+$ to the unicellular green alga Pseudokirchneriella subcapitata: Model development and validation with surface waters. Science of the Total Environment. 407(6): p. 1901-1914.

11. Deleebeeck, N.M., De Schamphelaere K.A., Janssen C.R. (2008) A novel method for predicting chronic nickel bioavailability and toxicity to Daphnia magna in artificial and natural waters. Environmental Toxicology and Chemistry: An International Journal, 27(10): p. 2097-2107.

12. De Schamphelaere K.A., Janssen, C. (2002) A biotic ligand model predicting acute copper toxicity for Daphnia magna: the effects of calcium, magnesium, sodium, potassium, and pH. Environ Sci Technol. 36(1): p. 48-54.

13. Farrell A.P., Wood C.M., Brauner C.J. (2012) Homeostasis and toxicology of non-essential metals. Journal of Fish Biology. 83(5): p. 1476-1477.

14. Favus, M.J., et al. (1989) Effects of quinacrine on calcium active transport by rat intestinal epithelium. American Journal of Physiology-Gastrointestinal and Liver Physiology. 257(5): p. G818G822.

15. Fernando, C.H. (1979), The freshwater zooplankton of Sri Lanka, with a discussion of tropical freshwater zooplankton composition. Bulletin of the Fisheries Research Station, Sri Lanka. 29(1-2): p. 11-54.

16. Gama-Flores J.L., Sarma S., Nandini S.(2008) Combined effects of exposure time and copper toxicity on the demography of Moina macrocopa (Crustacea: Cladocera). Journal of Environmental Science and Health, Part B, 44(1): p. 86-93.

17. Gensemer R.W., Playle R.C. (1999) The bioavailability and toxicity of aluminum in aquatic environments. Critical reviews in environmental science and technology. 29(4): p. 315-450.

18. Korovchinsky, N.M. (2013) Cladocera (Crustacea: Branchiopoda) of South East Asia: history of exploration, taxon richness and notes on zoogeography. Journal of Limnology, 72: p. e7.

19. Hamilton M.A., RussoR.C., Thurston R.V. (1977) Trimmed Spearman-Karber method for estimating median lethal concentrations in toxicity bioassays. Environmental science \& technology 11(7): p. 714-719

20. Hayashi, T.I. (2013) Applying biotic ligand models and Bayesian techniques: Ecological risk assessment of copper and nickel in Tokyo rivers. Integrated environmental assessment and management 9(1): p. 63-69.

21. Hoang T.H.T., Van A.D., Nguyen H.T.T. (2017) Driving variables for eutrophication in lakes of $H$ anoi by data-driven technique. Water and environment journal. 31(2): p. 176-183.

22. Le Thanh, H., Bui M.T., Cacot P., Lazard J. (1999) Larval rearing of the Mekong catfish, Pangasius bocourti (Pangasiidae, Siluroidei): substitution of Artemia nauplii with live and artificial feed. Aquatic 
Living Resources 12(03):229 - 232.

23. Mager, E.M., et al. (2011) Influences of water chemistry on the acute toxicity of lead to Pimephales promelas and Ceriodaphnia dubia. Comparative Biochemistry and Physiology Part C: Toxicology \& Pharmacology. 153(1): p. 82-90.

24. Markich S.J., Jeffree R.A. (1994) Absorption of divalent trace metals as analogues of calcium by Australian freshwater bivalves: an explanation of how water hardness reduces metal toxicity. Aquatic toxicology 29(3-4): p. 257-290.

25. McGeer J.C., et al. (2000) A physiologically based biotic ligand model for predicting the acute toxicity of waterborne silver to rainbow trout in freshwaters. Environmental science \& technology. 34(19): p. 4199-4207.

26. Naito, W., et al. (2010) Exposure and risk assessment of zinc in Japanese surface waters. Science of the Total Environment.408(20): p. 4271-4284.

27. Niyogi S., Wood C.M. (2004) Biotic ligand model, a flexible tool for developing site-specific water quality guidelines for metals. Environmental Science \& Technology. 38(23): p. 6177-6192.

28. Nguyen T.L.H., Ohtsubo M., Li L.Y., Higashi T. (2007) Heavy metal pollution of the To-Lich and KimNguu River in Hanoi City and the industrial source of the pollutants. J. Fac. Agric. Kyushu Univ. 52, $141 \mathrm{e} 146$.

29. Nys, C., et al. (2014) Development and validation of a biotic ligand model for predicting chronic toxicity of lead to Ceriodaphnia dubia. Environmental toxicology and chemistry. 33(2): p. 394-403.

30. Pareja-Carrera, J., et al., (2020) Effect of mineral supplementation on lead bioavailability and toxicity biomarkers in sheep exposed to mining pollution. Environmental Research: p. 110364.

31. Pham, T.H., Anh TN Doan, Nha T Dao , Hai H Dao, Hoang T.T.H (2018) Metal bioaccumulation in fishes and macro zooplankton in some lakes in Ha noi. Vietnam Journal of Science and Technology. 56(2C): p. 96-103.

32. Playle R.C., Dixon D.G., Burnison K. (1993) Copper and cadmium binding to fish gills: estimates of metal-gill stability constants and modelling of metal accumulation. Canadian Journal of Fisheries and Aquatic Sciences. 50(12): p. 2678-2687.

33. Playle, R.C., Gensemer R.W., Dixon D.G. (1992) Copper accumulation on gills of fathead minnows: Influence of water hardness, complexation and $\mathrm{pH}$ of the gill micro-environment. Environmental Toxicology and Chemistry: An International Journal. 11(3): p. 381-391.

34. Renaudin, M., et al. (2018) The coastal environment affects lead and sodium uptake by the moss Hypnum cupressiforme used as an air pollution biomonitor. 193: p. 506-513.

35. Sakamoto, M., et al. (2018) Health impacts and biomarkers of prenatal exposure to methylmercury: lessons from Minamata, Japan. Toxics, . 6(3): p. 45.

36. Sheedy, B.R., et al. (1991) Effects of pollution on freshwater organisms. Research Journal of the Water Pollution Control Federation 63(4):619-696. 
37. Shoji R., Taniguchi T (2016) Prediction of ecotoxicity of copper to an Asian clam by the Biotic Ligand Model in river water with changing salt concentration owing to tides. Journal of Japan Society on Water Environment. 39(4): p. 109-113.

38. Stumm, W. and J.J. Morgan (2012) Aquatic chemistry: chemical equilibria and rates in natural waters. John Wiley \& Sons., pp1040.

39. Tobiason, S., et al. (2018) BLM-Based Ambient Water Quality Criteria and FMBs for Four Metals in Surface Waters of the Pajarito Plateau, New Mexico.

40. Uddin, M.J., Jeong Y.-K. (2021) Urban river pollution in Bangladesh during last 40 years: potential public health and ecological risk, present policy, and future prospects toward smart water management. Heliyon, 2021. 7(2): p. e06107.

41. Von der Ohe P.C., Liess M. (2004) Relative sensitivity distribution of aquatic invertebrates to organic and metal compounds. Environmental Toxicology and Chemistry: An International Journal. 23(1): p. 150-156.

42. Wang, W., et al. (2017) Application of Biotic Ligand Model in Predicting Copper Acute Toxicity to Carp (Cyprinidae). Bulletin of environmental contamination and toxicology 98(1): p. 22-26.

43. Wang, C., et al. (2011) Application of the biotic ligand model to predict copper acute toxicity to Medaka fish in typical Chinese rivers. Water Science and Technology 64(6): 1277-1283.

44. Yao, S., et al. (2009) Lead pollution recorded in sediments of three lakes located at the middle and lower Yangtze River basin, China. Quaternary International. 208(1-2): p. 145-150.

45. Zhao, M., et al. (2017) Effects and mechanisms of meta-sodium silicate amendments on lead uptake and accumulation by rice. Environ Sci Pollut Res Int.24(27):21700-21709.

46. Zhou, D.-M., et al. (2011) A QICAR approach for quantifying binding constants for metal-ligand complexes. Ecotoxicology and environmental safety 74(4): p. 1036-1042.

47. Zou, E. and S. Bu (1994), Acute toxicity of copper, cadmium, and zinc to the water flea, Moina irrasa (Cladocera). Bulletin of environmental contamination and toxicology, 52(5): p. 742-748.

\section{Tables}

Table 1. Characteristics of water quality in Lake of Hanoi and values of experiment $\mathrm{EC}_{50}\left(\mathrm{~Pb}^{2+}\right)$ with M.dubia 


\begin{tabular}{|c|c|c|c|c|c|c|c|c|c|}
\hline Lakes & $\mathrm{pH}$ & $\begin{array}{l}\text { DOC, } \\
\mathrm{mg} / \mathrm{l}\end{array}$ & $\begin{array}{l}\mathrm{Ca}^{2+} \\
\mathrm{mg} / \mathrm{l}\end{array}$ & $\begin{array}{l}\mathrm{Mg}^{2+} \text {, } \\
\mathrm{mg} / /\end{array}$ & $\begin{array}{l}\mathrm{Na}^{+} \\
\mathrm{mg} / \mathrm{l}\end{array}$ & $\begin{array}{l}\mathrm{K}^{+}, \\
\mathrm{mg} / \mathrm{l}\end{array}$ & $\begin{array}{l}\mathrm{SO}_{4}{ }^{2-}, \\
\mathrm{mg} / \mathrm{l}\end{array}$ & $\begin{array}{l}\mathrm{Cl}^{-} \\
\mathrm{mg} / \mathrm{I}\end{array}$ & $\begin{array}{l}\mathrm{EC50} \\
\mathrm{T}_{\mathrm{Pb}} \\
\mu \mathrm{g} / \mathrm{l}\end{array}$ \\
\hline Lang & 7,5 & 2.3 & 37,8 & 12,98 & 1,39 & 1,85 & 7,98 & 65,34 & 510 \\
\hline $\begin{array}{l}\text { Hai Ba } \\
\text { Trung }\end{array}$ & 8,1 & 5 & 45,23 & 7,86 & 9,13 & 2,5 & 15,98 & 124,23 & 980 \\
\hline $\begin{array}{l}\text { Thanh } \\
\text { Nhan }\end{array}$ & 8,3 & 7.3 & 54,7 & 8,75 & 18,5 & 2,43 & 9,54 & 345,41 & 950 \\
\hline Dong Da & 7,2 & 12 & 45,78 & 7,98 & 1,63 & 2,23 & 12,54 & 45,67 & 300 \\
\hline Bay Mau & 7,85 & 11,8 & 64 & 4,8 & 54,2 & 8,23 & 15,65 & 111,825 & 600 \\
\hline $\begin{array}{l}\text { West } \\
\text { Lake }\end{array}$ & 8,2 & 2,78 & 38,23 & 5,73 & 21,6 & 14,2 & 23,65 & 167,56 & 320 \\
\hline $\begin{array}{l}\text { Nam } \\
\text { Dong }\end{array}$ & 8,3 & 5 & 40,54 & 6,95 & 16,3 & 8,34 & 7,87 & 115,33 & 960 \\
\hline $\begin{array}{l}\text { Van } \\
\text { Chuong }\end{array}$ & 8,1 & 5.2 & 32,56 & 3,24 & 2,98 & 2,32 & 20,56 & 168,54 & 890 \\
\hline Kim Lien & 7,85 & 4.5 & 38,96 & 8,64 & 2,63 & 3,23 & 23,94 & 345 & 680 \\
\hline $\begin{array}{l}\text { Linh } \\
\text { Dam }\end{array}$ & 7,3 & 18 & 35,9 & 14,4 & 7,16 & 10,34 & 31,45 & 79 & 430 \\
\hline $\begin{array}{l}\text { Truc } \\
\text { Bach }\end{array}$ & 8,3 & 4,8 & 47,82 & 8,64 & 60,1 & 16,2 & 23,94 & 275 & 980 \\
\hline $\begin{array}{l}\text { Quan } \\
\text { Son }\end{array}$ & 8,35 & 6,98 & 46,82 & 18,4 & 1,48 & 19,6 & 7,12 & 45,23 & 1200 \\
\hline Tuy Lai & 8,37 & 8,74 & 87,68 & 20,4 & 1,004 & 20,43 & 7,34 & 23,45 & 1450 \\
\hline
\end{tabular}

Table 2. Comparation of Biotic Ligand Model Constants (( $95 \%$ Confidence) for Binding of Cations to the Biotic Ligand of Moina dubia (This Study) and Stability Constants for Inorganic Copper ComplexesbDaphnia magna (Naito et al 2010) và Pimephales promelas (Shoji et al . 2016) 


\begin{tabular}{|c|c|c|c|}
\hline \multirow[t]{2}{*}{$\log K$} & \multicolumn{3}{|c|}{ Model coefficient } \\
\hline & $\begin{array}{l}\text { Moina dubia } \\
(\mathrm{Pb})\end{array}$ & $\begin{array}{l}\text { Daphnia Magna (Cu) (Naito et al } \\
\text { 2010) }\end{array}$ & $\begin{array}{l}\text { P.promelas (Cu) (Shoji et al } \\
\text { 2016) }\end{array}$ \\
\hline $\begin{array}{l}\text { Log } \\
\mathrm{K}_{\mathrm{CaBL}}\end{array}$ & 4,39 & 3,47 & 3,6 \\
\hline $\operatorname{LogK}_{M g B L}$ & 4,47 & 3,58 & 3,6 \\
\hline $\operatorname{LogK}_{\mathrm{NaBL}}$ & 3,92 & 3,19 & 3,19 \\
\hline $\operatorname{LogK}_{K B L}$ & 4.34 & - & - \\
\hline $\log K_{H B L}$ & 3,72 & 5,4 & 5,4 \\
\hline
\end{tabular}

Table 3. Comparing EC50 values of lead to M.dubia from experiments with natural lake water and results from pre- and post-calibrated models 


\begin{tabular}{|c|c|c|c|}
\hline Lakes & $\begin{array}{l}\text { Experimental } \\
\mathrm{EC}_{50-\mathrm{Pb}^{2+}}{ }^{2+}\end{array}$ & $\begin{array}{l}\text { Calculated } \mathrm{EC}_{50 \mathrm{~Pb}}{ }^{2+} \text { before } \\
\text { calibration }\end{array}$ & $\begin{array}{l}\text { Calculated } \mathrm{EC}_{50 \mathrm{~Pb}}{ }^{2+} \text { after } \\
\text { calibration }\end{array}$ \\
\hline Lang & 2.54 & 3.24 & 2.51 \\
\hline $\begin{array}{l}\text { Hai Ba } \\
\text { Trung }\end{array}$ & 2.46 & 3.12 & 2.42 \\
\hline $\begin{array}{l}\text { Thanh } \\
\text { Nhan }\end{array}$ & 2.65 & 3.43 & 2.66 \\
\hline Dong Da & 2.55 & 3.28 & 2.55 \\
\hline Bay Mau & 3.04 & 3.94 & 3.06 \\
\hline Ba Mau & 3.07 & 3.97 & 3.08 \\
\hline $\begin{array}{l}\text { West } \\
\text { Lake }\end{array}$ & 2.54 & 3.25 & 2.53 \\
\hline $\begin{array}{l}\text { Nam } \\
\text { Dong }\end{array}$ & 2.52 & 3.18 & 2.47 \\
\hline $\begin{array}{l}\text { Van } \\
\text { Chuong }\end{array}$ & 2.05 & 2.65 & 2.06 \\
\hline Kim Lien & 2.32 & 3.01 & 2.34 \\
\hline Linh Dam & 3.76 & 3.55 & 2.76 \\
\hline Truc Bach & 3.25 & 4.10 & 3.18 \\
\hline Truc Bach & 2.30 & 3.39 & 2.63 \\
\hline Quan Son & 3.05 & 3.68 & 2.86 \\
\hline Tuy Lai & 3.35 & 4.33 & 3.36 \\
\hline Quan Son & 3.00 & 3.85 & 2.99 \\
\hline Tuy Lai & 3.20 & 4.20 & 3.26 \\
\hline
\end{tabular}

Figures 


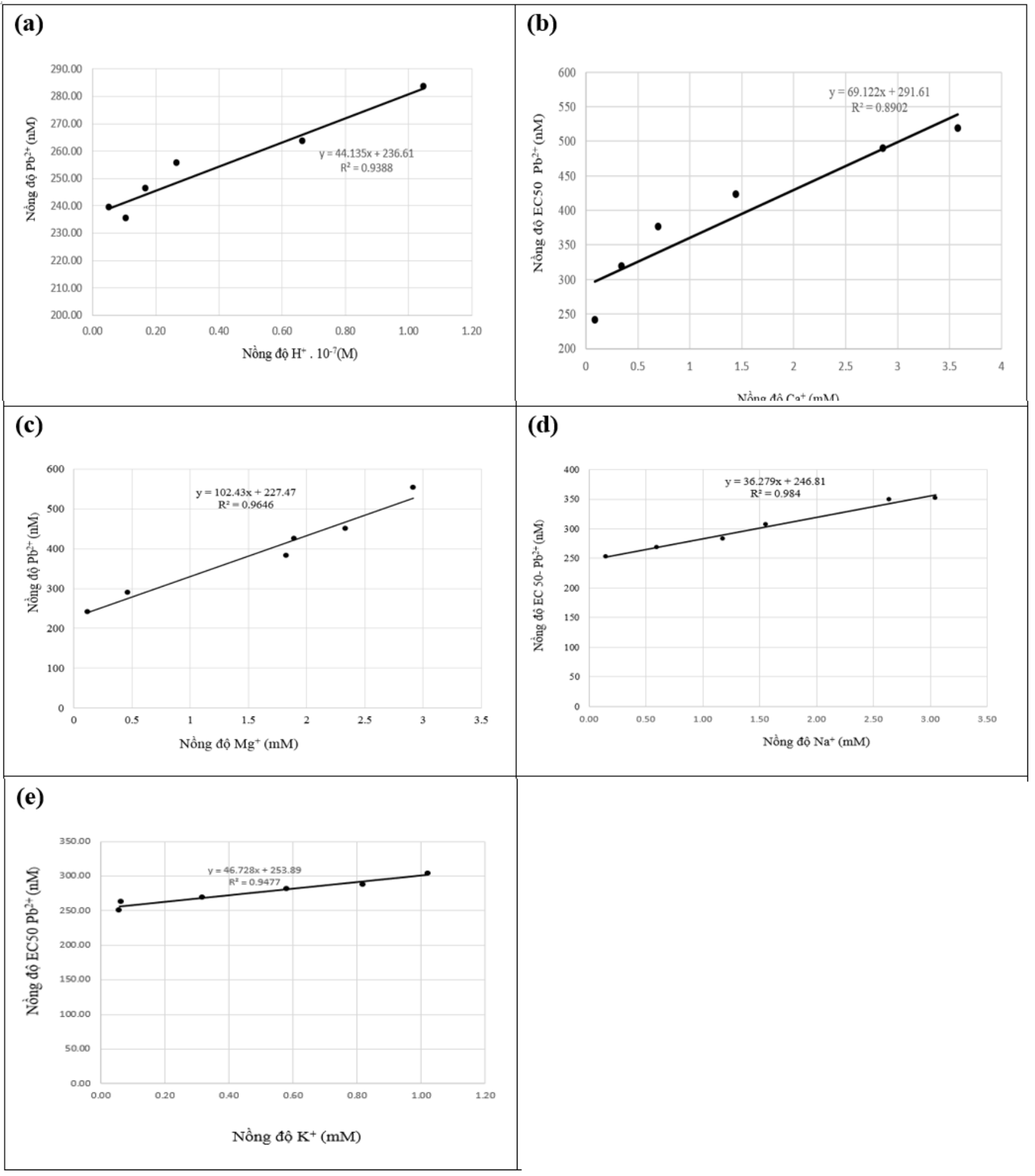

Figure 1

Relation between concentration of $\mathrm{H}+(a), \mathrm{Ca} 2+(\mathrm{b}), \mathrm{Mg} 2+(\mathrm{c}), \mathrm{Na}+(\mathrm{d}), \mathrm{K}+(\mathrm{e})$ and $\mathrm{EC} 50-\mathrm{Pb} 2+$ 


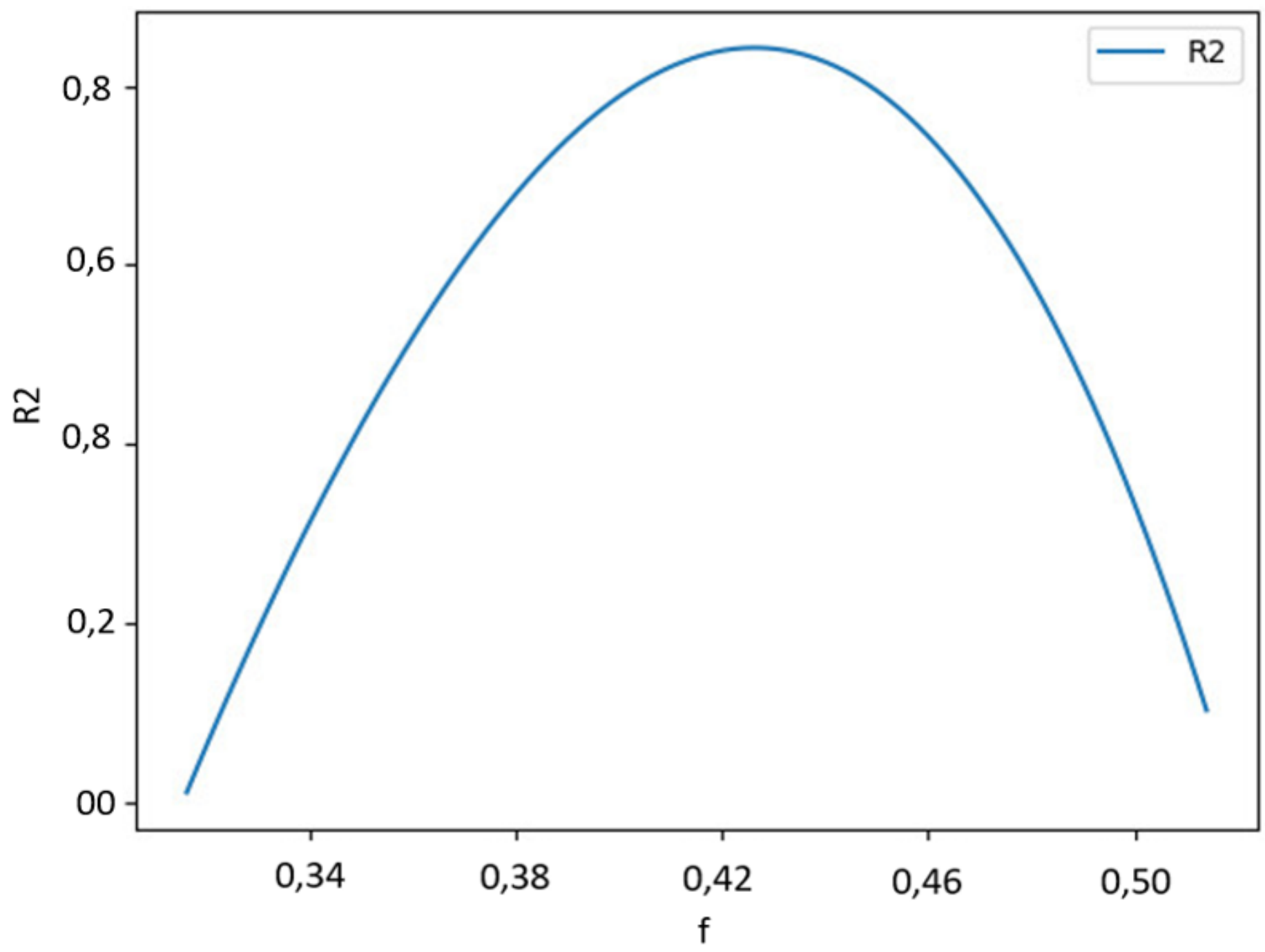

Figure 2

Validation $\mathrm{fPbBL} 50$ at lab experiment in control medium 


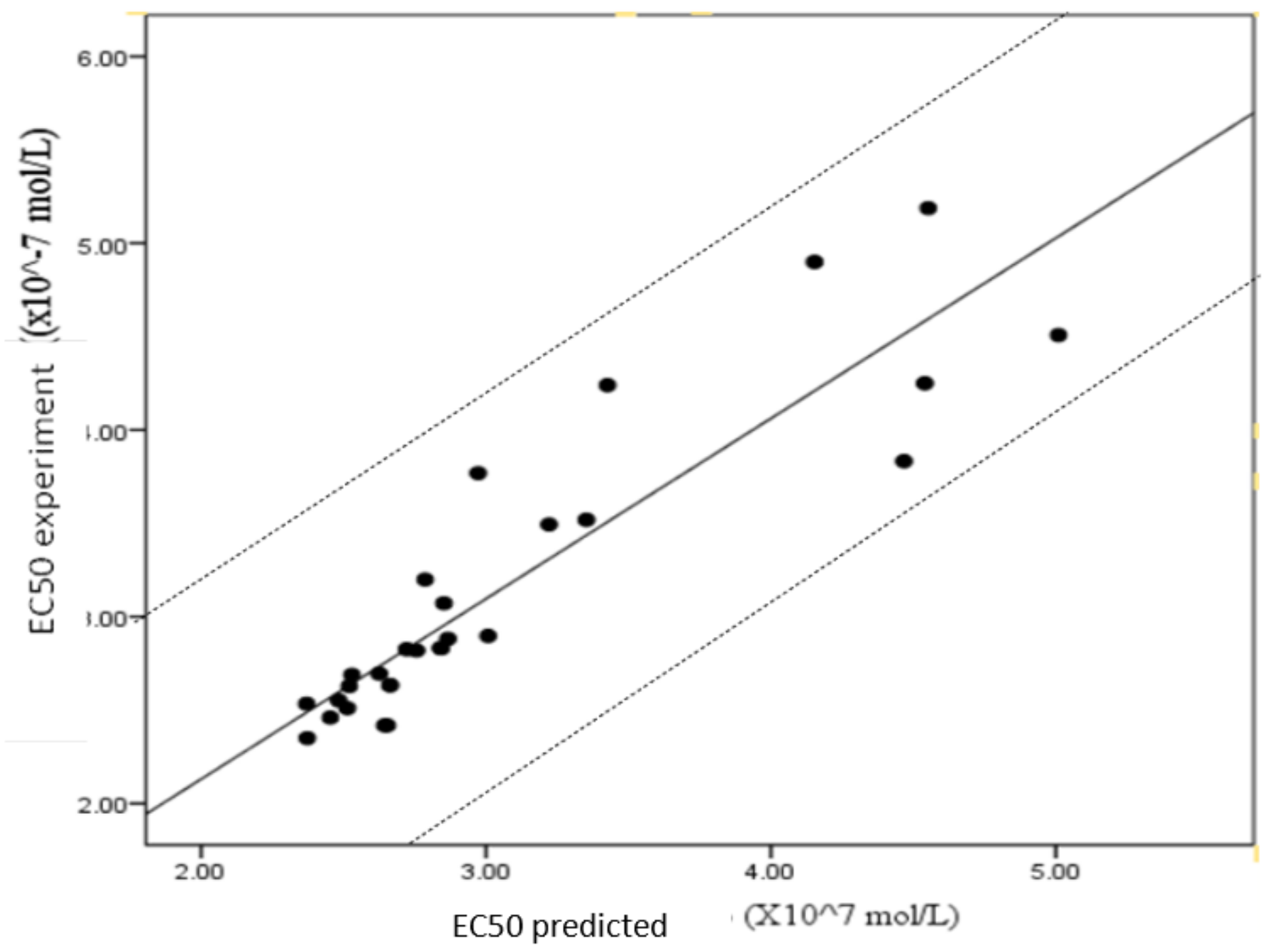

Figure 3

EC50 experiment and EC50 from model with $f=0.42$ 


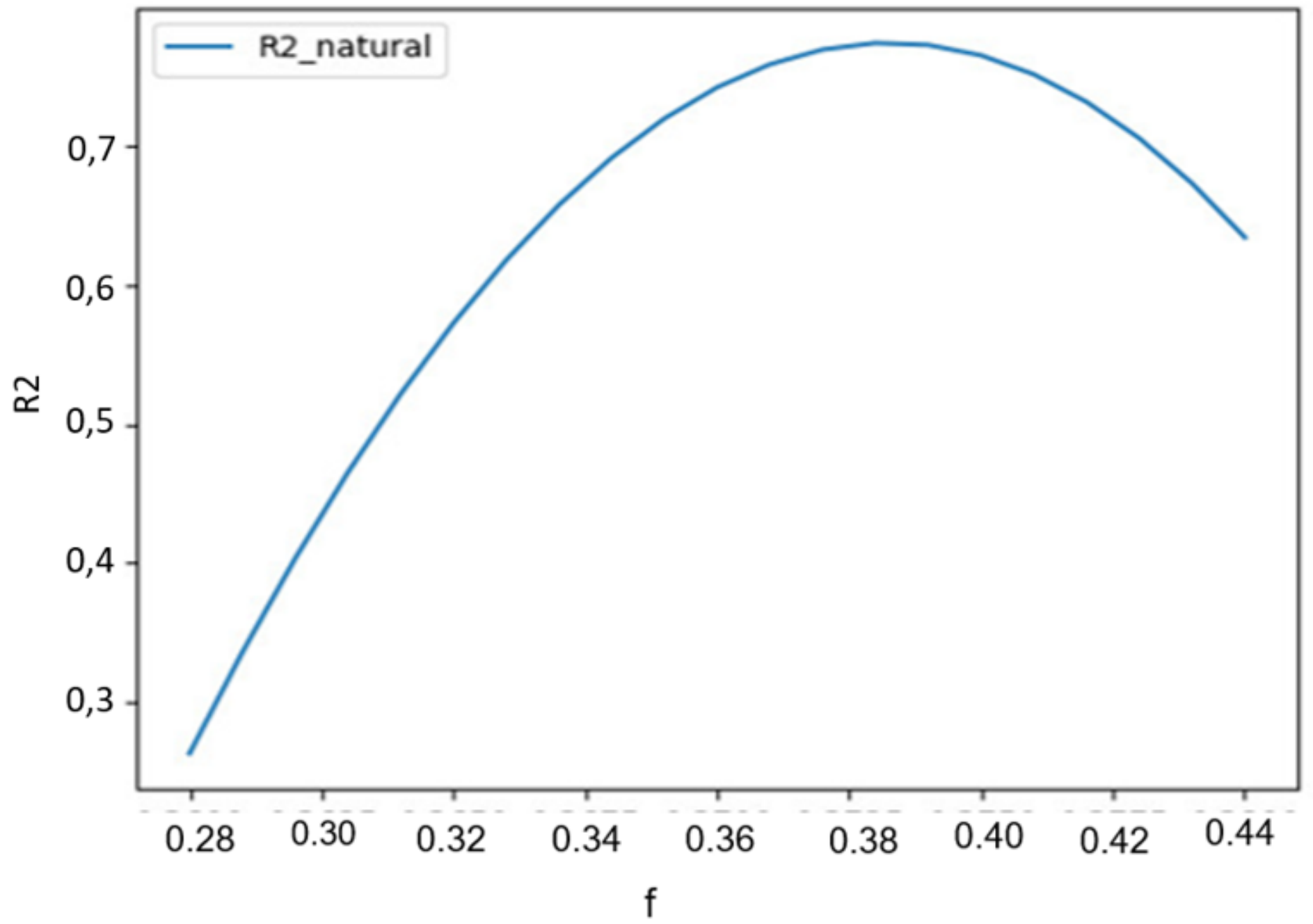

Figure 4

Validation $\mathrm{fPbBL} 50$ at lab experiment in natural medium 


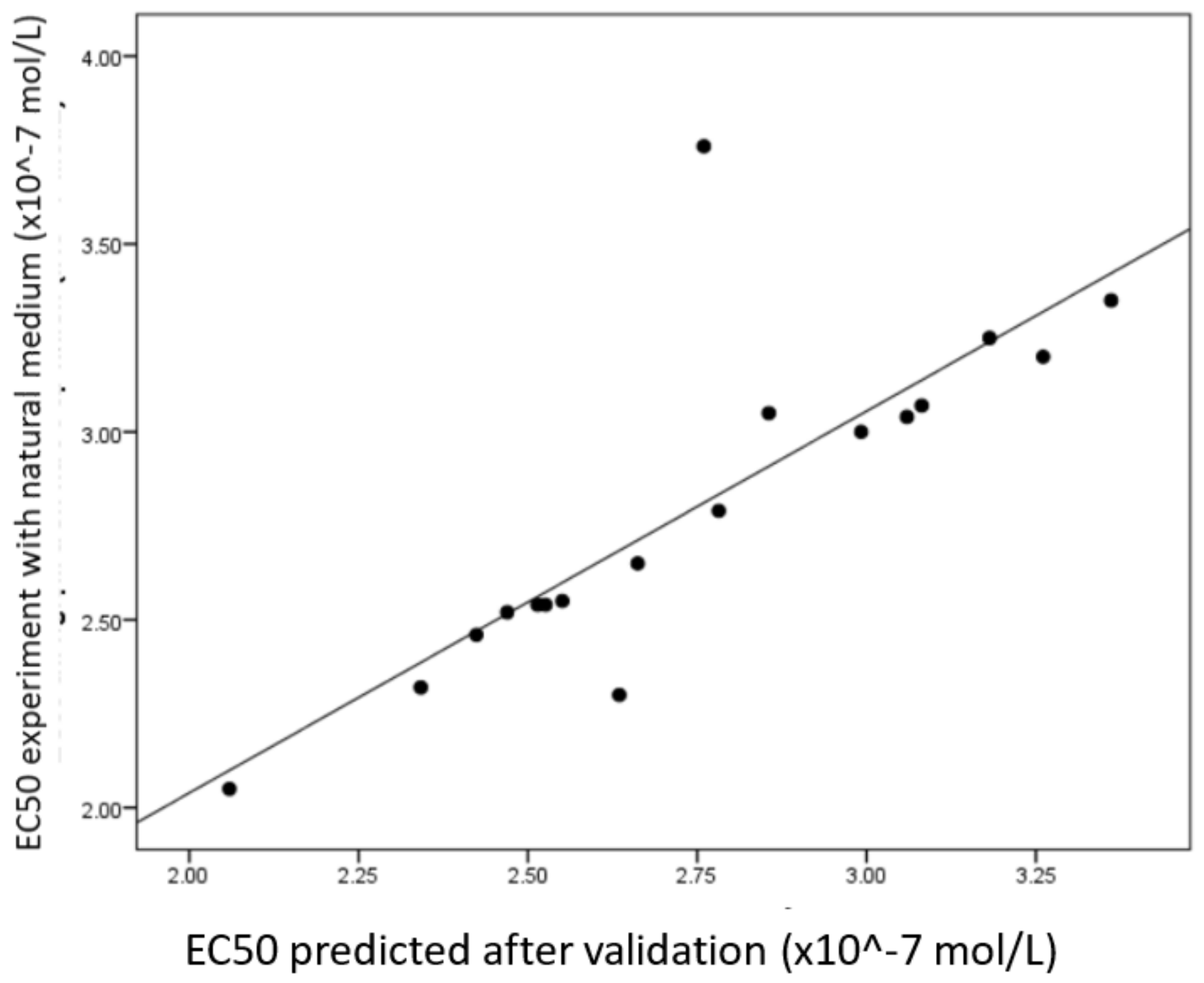

Figure 5

EC50 experiment with natural medium and EC50 from model after validation 